\title{
Global Oil Price Volatility and Foreign Direct Investment Inflows in Kenya
}

\author{
Julians Amboko $^{1 *} \quad$ Kennedy Ocharo, 2 \\ 1.School of Economics, Kenyatta University, PO box 43844-00100, Nairobi \\ 2.School of Business and Economics, University of Embu, PO Box 6-60100, Embu
}

\begin{abstract}
External capital flows play a crucial role in driving investment and economic growth in financial resource constrained countries such as Kenya. As such, the vulnerability of a country's foreign direct investment flows to external shocks is a key area of research interest. In the past, studies on Kenya's vulnerability to oil price volatility have focused on its pass-through effects through inflation and the exchange rate. To date, there is a gap in literature with regard to assessment of how oil price volatility impacts foreign direct investment flows into Kenya and this has been premised on Kenya being an oil importing economy. In August 2019, however, Kenya made its first commercial sale of oil in the global market selling 200, 000 barrels and realizing USD 12.0 million (Kes 1.2 billion) in proceeds. The first objective was to establish the trend of global oil price volatility between 1970 and 2016 and to investigate the effect of global oil price volatility FDI inflows in Kenya. The study used GARCH model encompassing Kenya's FDI inflows as the endogenous variable and exchange rate, external balance, inflation, net exports, real interest rate and gross domestic product growth as exogenous variables. The GARCH model entailed estimating two equations, the mean and the variance equations, at the same time with the residuals of the former allowing one to model the volatility of exogenous variables. Multiple linear regression analysis was used to establish strength of linear relationship between the selected macroeconomic variables and FDI inflows in Kenya. The findings of the first objective using $\operatorname{ARCH}(1,1)$ model, yielded a statistically significant coefficient for the lag, $1=1.032$, the second objective, the results of multiple linear regression analysis established that only Global Price of Oil (USD per Barrel) $\beta_{1}=-7969894$ and External Balance (USD) $\beta_{2}=-0.158033$ were statistically significant at $5 \%$ level. The findings provide important insights for economic policy implementers regarding how to take necessary measures to counter the effect of global oil price volatility in order to realize sustainable inflow of FDI in the country.
\end{abstract}

Keywords: Volatility; foreign direct investment; oil price

DOI: $10.7176 / \mathrm{JESD} / 12-8-05$

Publication date: April $30^{\text {th }} 2021$

\section{Introduction}

Global oil price volatility has received considerable attention from scholarly publications in economic discipline. Accordingly, this has led to varied conceptualizations of what constitutes 'volatility' (Troiano \& Villa, 2020; Hachula \& Rieth, 2020). Several scholars have argued that volatility in oil prices refers to the dispersion of the price of oil in the global market from its average over a given period as argued (Sauter \& Awerbuch, 2003; Gulen \& Michot, 2012; Ebrahim, Inderwildi \& King, 2014). In addition, Gandorfer, Porsch and Bitsch (2017) contend that volatility with respect to price has to do with the directionless measure of the extent of the variability of a price of a given commodity.

At the same time, there has been substantive research studies articulating the role of foreign direct investment (FDI) in economies around the World. Foreign direct investment, has therefore been defined as the net inflows of investment to acquire a lasting management interest (Haider, Gul, Afridi \& Batool, 2017). Sohail and Mirza (2020) define FDI as the increase in the book value of the net worth of investment of one country held by the investor of an. Additionally, foreign direct investment has also been defined as the ratio of foreign direct investment to total GDP of a given country (Lv, Cheng \& Wang, 2020).

On the basis of the existing research gap relating to the question of oil price volatility and FDI within the Kenyan context, the present study sought to interrogate how volatility in the Global price of oil influences foreign direct investments. Accordingly, the study drew upon theoretical frameworks, together with empirical studies captured from the global, regional as well as local perspectives.

\subsection{Theoretical review}

Mundell-Fleming Model

The Mundell-Fleming Model, is a theoretical framework developed in the early 1960s by Marcus Fleming and Robert Mundell, in order to take into account capital inflows and shocks that may stem from capital inflows into the open economy Keynesian model (Boughton, 2002). In addition, Weeks (2008), articulate that MundellFleming Model stipulates that monetary policy is more effective in comparison to fiscal policy in the environment that is characterized by market determine the exchange rate and unrestricted flow of capital in and out of the 
economy.

Welfens (2011), opined that the growing significance of FDI as a key variable in the global macroeconomic necessitates inclusion in the Mundell-Fleming model. Accordingly, the assumptions underlying the MundellFleming model were relevant in the present study and outlined as follows:

1. The model assumes existence of perfect mobility of capital such that there exists little, if any, barriers to inflow and outflow of funds across borders. Unlike peer economies such as Ethiopia and Angola, Kenya has neither foreign exchange controls nor does it bar foreign investors from repatriating capital and profits (UNCTAD, 2012). This creates an environment that has relatively high capital mobility.

2. The model assumed a small open economy. The study of interest focuses on a small open economy. Wynne (2007) defined a small open economy as one which is unable to dictate the terms on which global trade takes place, a characteristic that aptly fits Kenya.

The Mundell-Fleming model is defined by two equations whereby the IS curve and the LM curve represent equilibrium in the goods and money markets, respectively.

$I S: Y=C(Y-T)+I\left(r^{\prime}\right)+G+N X(e)$

$L M: \frac{M}{P}=L\left(r^{\prime}, y\right)$

In Equation 2.1, Y, C, T, I, r', G, NX, and a are representative of the level of income, consumption, taxes, investment, the rate of interest prevailing in the international market, government expenditure, net exports and the exchange rate, respectively. In Equation 2.2, M, P and y are representative of the prevailing supply of money, price level and real income respectively.

Since its inception, the Mundell-Fleming model has been modified differently depending on the study of interest. Sikdar (2008), in a study on capital flows into developing economies, used the model as provided in Equations 2.3 and 2.4 in assessing the impact of policy interventions by the Reserve Bank of India on capital inflows. Equation 2.3 suggests that savings (S) is given by the summation of the level of investment and the aggregation of net exports whilst Equation 2.4 indicates that the foreign exchange market is equilibrated when net capital inflows (NCI) equals the current account deficit (-NX).

$I S: S=I+N X$

$B P=N C I-N X=0$

This study, on global oil price volatility and FDI inflow in Kenya, adopted the Mundell-Fleming model as modified by Johnson, Zuber and Gandar (2006). The modification began by expressing a country's external balance (EB) in terms of imports, exports and capital flows. Equation 2.5 showed that the strength of the local currency and the domestic price level were key in determining exports whilst imports were dependent on real income, price and the exchange rate. $\mathrm{F}^{\mathrm{n}}$ represented net capital inflow.

Dynamic Macroeconomic Theory

This theory holds that the inflow of investment in a country is determined by two key factors - multinationals' long-term strategic focus and developments in the host country's macroeconomic environment (Beghum, Sannassee, Seetanah \& Lamport, 2011; Feiguine \& Solovjova, 2014). In exploring this theory, Hayee, Jameel and U1 Hasan (2016) argued that timing and the overall macroeconomic environment were crucial determinants of the amount of FDI inflow an economy receives. Macroeconomic aspects whose changes informed FDI inflow include GDP, real exchange rate, productivity, openness of the economy and domestic investment (Jugurnath, Chuckun \& Fauzel, 2016).

Sanchez (2011) established that an uptick in the cost of a barrel of oil bears a significant negative implication on Kenya's GDP. Similarly, Gachara (2015) argued that volatility in the cost of a barrel of oil in the global market triggered weakness of the local currency and inflicted a negative impact on real GDP growth. This view is corroborated by Makau (2017) whose study found that a spike in the price of oil leads to weakening of the Kenya Shilling, increase in inflation and a slowdown in the GDP growth rate.

Accordingly, the dynamic macroeconomic theory was applicable in the present study given the fact that a number of preceding studies have revealed how pass through effects from volatility in the cost of a barrel of oil in the global market impact the same variables driving inflow of FDI.

$E B=X-M+F^{n}=X\left(P, E_{0}\right)-M\left(y, P, E_{0}\right)+F^{n}(r)$

\subsection{Empirical review}

The trend of global oil price volatility between 1970 and 2016

The first objective explored the trend of global oil price volatility between the years 1970 to 2016 . The findings of prior studies in these respects reveals various statistical and econometric techniques of modelling such volatile data. Klein and Walther (2016), whose study involved collection of similar kind of data approach trend analysis of the volatility of oil price using GARCH models.

In the recent past, Chatziantoniou, Filippidis, Filis and Gabauer (2021) set out to investigate the impact of macroeconomic variables such as oil demand, oil inventory, financial market uncertainty among others; and how 
they impacted on realised volatility. The study analysed monthly data over the period 1990:1-2019:5, and after analysing of the findings using time-varying parameter vector autoregressive (TVP-VAR), the results confirmed how the selected factors were conducive to higher levels of realised oil price volatility notably in the short run.

Further, Lyu, Tuo, Wei and Yang (2021) explored time-varying effects of Global Economic Policy Uncertainty (GEPU) shocks on the volatility of two international pricing benchmarks for crude oil-Brent and West Texas Intermediate (WTI) crude oil price- under dynamic structural changes. The findings suggested that GEPU on crude oil volatility was time-variant, with amplification of the same exhibited under extreme market conditions; notably 2007-2009 financial crisis and 2010-2012 European sovereign debt crisis. Moreover, the findings pointed to the existence of differences between the responses of Brent crude oil volatility and WTI crude oil price volatility to GEPU shocks.

In a survey among Sub-Saharan African countries, Abdulkarim, Akinlaso, Hamid, and Ali (2020), stressed on the importance of GARCH models fitting the trend of oil price volatility. In addition, empirical studies in South Africa by Sekati, Tsoku, and Metsileng (2020), underscored the importance of the models in explaining volatility associated with the price of oil. A similar modelling approach was used in a survey conducted recently in Brazil, Mexico and 35 OECD by Alao and Payaslioglu (2021), underscored the importance of the GARCH model in analysing volatility of the global oil price.

Apparently, these studies add credence to the use of GARCH models in modelling volatility associated with the global price of oil. As such, the present study also used similar approach in modelling volatility for the data captured between the years 1978 and 2016, so as to answer the first research question of the study.

The effect of global oil price volatility on FDI inflows in Kenya

The second study objective analysed how FDI was influenced by global oil price volatility. To accomplish this, global, regional and context-specific studies were reviewed with the interest of identifying how sudden changes in the price of oil at a global level influences FDI inflows in the country.

In South America, Francis and Restrepo-Angel (2018) study focused on Colombian economy used data collected between the first quarter of the Year 2002 and the third quarter of the Year 2017 analysed data using structure of the data autoregressive model where the findings indicated how foreign direct investment was influenced by changes in the price of oil. Given that the study was conducted further away from the present study context the findings offer important insights to investigate how foreign direct investment in Kenya are affected by global oil price volatility.

Elheddad, Thapa-Parajuli and Alharthi (2020), in their survey on Gulf Countries under the Gulf Cooperation Council umbrella reaffirm the existence of a relationship between FDI inflows and sudden shocks in the Global oil price. Even as the study was conducted outside the context of the present study the findings represent important insights regarding the intersection between oil price volatility and FDI inflows.

Further, empirical studies in African countries have given wide ranging perspectives with regard to the intersection between the fluctuations of the price of oil and foreign direct investment inflows. This is reaffirmed in a study in Nigeria by Adejumobi and Julius (2017) who used Structural Vector Autoregressive model on data collected between the years 1980 to 2014, and the findings established that shocks resulting from the price of crude oil had an influence on FDI inflow in the country.

In Kenya, Gachara (2015) analysed how shocks related to the crude oil price affected by Kenyan Shilling, the domestic price levels, the quantity of money in supply and the economy's overall growth momentum. As such, analysis of data collected between the years 1991 to 2014 using structural vector autoregressive model established relationship between the selected macroeconomic variables. The present study however focused on modelling volatility of the global oil price, and analyse how it influences FDI inflows in Kenya.

The influence of other macroeconomic variables on FDI inflows

Empirical studies have demonstrated how various macroeconomic variables have influenced FDI in various countries. For instance, a survey conducted in Indonesia, Malaysia, Singapore, Philippines, Thailand and Brunei by DdFazira and Cahyadin (2018), after conducting panel data analysis using fixed effects model established significant influence of real interest rates on FDI inflows.

Research studies have also found out that official exchange rate can have a significant influence on foreign direct investments as observed in a survey in South Korea by Lindström and Sten (2018), who after employing ordinary least squares regression model established that official exchange rate had a statistically significant effect on FDI inflow.

Moreover, studies have also established that headline inflation can have an influence on foreign direct this is an agreement with water system used by Habimana (2018), after conducting a survey in Rwanda found out that headline inflation can have an influence on FDI inflows in the country.

In addition, research studies have also shown that real GDP growth can influence FDI inflows in a country. This is in line with what was found out in a study by Talwar and Srivastava (2018), after conducting a survey in several countries including Bhutan, Ethiopia, India, Brazil, USA and UK established that real GDP growth can have a statistically significant influence on foreign direct investment. Additionally, a survey carried out in European 
countries by Sayari, Sari and Hammoudeh (2018) underscored the importance of value-added components of GDP on FDI inflows.

Prior research studies have established that external balance can influence FDI inflows in a country. This is in agreement with what was observed in a survey by Vlachos, Mitrakos, Tsimpida, Tsitouras and Bitzenis (2019), whose findings indicated that changes in the FDI inflows were influenced by external balance. Accordingly, the present study incorporated the above-mentioned macroeconomic variables alongside oil price volatility in a multiple linear regression model so as to establish how these variables influenced FDI inflows in Kenya.

\subsection{Statement of the problem}

The recent past has witnessed emergence of studies that have illuminated on the question of a foreign direct investments in several countries, at the same time discussed global oil price volatility and the existence of the connection between these two concepts. Elheddad, Thapa-Parajuli and Alharthi (2020), in a survey on Oil rich Gulf countries illustrated the existence of a relationship between the price of oil and foreign direct investments. In Africa, research studies have given perspectives on the interplay between foreign direct investment and oil price volatility. Mijiyawa (2012), reflects on the importance of understanding the Dynamics that underlie inflow of FDI in Africa. Additionally, Kiiru (2014) found that the magnitude of the impact of resource prices on FDI-to-GDP ratio in Sub-Saharan Africa had increased over the years and asserted that volatility of resource prices played an increasingly significant role in changes in FDI-to-GDP ratio.

In East Africa, studies have illuminated on the linkages between foreign direct investment and uncertainties in the price of oil. While taking into consideration Uganda's prospective commencement of oil exports in early 2020, through postponement of planned spending by multinationals. Tumusiime-Mutebile (2015) articulates on how price shocks undermine FDI inflows in the Country. Toews and Vézina (2016) add that in developing countries such as Kenya discoveries of natural resources can bring about an increase in FDI inflow that developing countries such as Kenya

Fairly recent studies on FDI inflow in Kenya presented wide-ranging perspectives. For instance, Toews and Vézina (2016) focused more on how the country would realize an increase in influence of FDI following discoveries of natural resources. In addition, other studies contend that quantitative drivers such as inflation rate, interest rate and development exchanger can have an influence on FDI (Njoroge 2016; Otieno \& Njuguna, 2016). Earlier on, studies had sought to capture qualitative factors such as political stability, strength of institutions as well as trade openness (Basemera \& Mutenyo, 2012; Mijiyawa, 2012).

Nonetheless, empirical studies focusing on Kenya have not considered the modelling of global oil price volatility between the years 1978 and 2016, in addition the question of how foreign direct investment inflows are influenced by global oil price volatility within the Kenyan context has not been explored. The findings from the present study therefore will offer important insights to stakeholders and policy advisors on how to take necessary measures to minimize the negative impact of global oil price volatility on the Kenyan foreign direct investment inflows.

\subsection{Research objectives}

The objectives of conducting the present study were:

1. To establish the trend of global oil price volatility between 1970 and 2016

2. To investigate the effect of global oil price volatility on FDI inflow in Kenya

\subsection{Research questions}

The present study was guided by the following research questions:

1. What is the trend of global oil price volatility between 1970 and 2016?

2. What is the effect of global oil price volatility on FDI inflows in Kenya?

\subsection{Methodology \\ 2.1 Research design}

The study used in an experimental research design that involved analysis of secondary data for FDI inflows, OPEC basket average price, Kenya Shilling to USD exchange rate, headline inflation, external balance, net exports and real GDP growth.

\subsection{Data collection}

Data for FDI inflows and the OPEC basket average price was sourced from UNCTAD and Bloomberg, respectively. Data for the nominal Kenya Shilling to USD exchange rate and headline inflation was sourced from Kenya National Bureau of Statistics. Data for external balance, net exports and real GDP growth was sourced from the World Bank. The impact of volatility in the price of oil on FDI inflows in a Kenya was analyzed using structural vector autoregressive methodology. 


\subsection{Theoretical model}

The theoretical underpinning of the study was guided by Mundell-Fleming model, which has emerged as one of the fundamental tools in analyzing how the macroeconomic environment responds to shocks emanating from capital inflows and determination of suitable policy response (Harris, 2009).

As such, the present study was anchored on Mundell-Fleming model of a small open economy as modified by Johnson, Zuber and Gandar (2006), the modification captured the country's external balance in terms of imports, exports, and capital inflows, as indicated earlier in Equation 2.5.the model was therefore rewritten to have the capital inflows as the endogenous variable as presented in Equation 3.1:

$F^{n}(r)=E B-X\left(P, E_{0}\right)+M\left(y, P, E_{0}\right)$

In its classical form as shown in Equation 3.1, $\mathrm{P}, E_{0}$ and y came in indirectly through $\mathrm{X}$ and $\mathrm{M}$. This adequately captured the variables intended for this study whilst necessitating introduction of interest rates (IR) and the price of oil (Oil.P) as shown in Equation 3.2:

$F D I=E B-X\left(P, E_{0}\right)+M\left(y, P, E_{0}\right)+\mathrm{IR}+$ Oil.P

The theoretical model was then fitted to the data using an empirical framework which is arrived at using the GARCH model as shown in Equation 3.7.

\subsection{Data analysis}

In order to answer the first research question the study used the Generalized Autoregressive Conditional Heteroskedasticity $(\mathrm{GARCH})$ model. The second research question was answered by adopting a multiple linear regression model in order to establish how aspects of oil price volatility influenced foreign direct inflows in Kenya. Diagnostic Tests

The study applied various diagnostic tests including unit roots tests using Augmented Dickey Fuller test and the Philip-Perron (PP) and testing for cointegration, as described below:

Augmented Dickey Fuller (ADF) Test

Said and 2Dickey (1984) augmented on the basic autoregressive unit root test to accommodate general ARMA (p, q) models with unknown orders and their test was referred to as the augmented Dickey- Fuller (ADF) test. ADF is based on the three different equations. For instance, taking this study's FDI variable to illustrate the underlying equations of the $\mathrm{ADF}$ and building on from Equation 3.2:

$F D I_{t}=\vartheta F D I_{t-1}+\sum_{i=1}^{p} \beta_{i} \Delta F D I_{t-i}+\varepsilon_{t}$

$F D I_{t}=\alpha_{0}+\vartheta F D I_{t-1}+\sum_{i=1}^{p} \beta_{i} \Delta \mathrm{FDI}_{t-i}+\varepsilon_{t}$

$F D I_{t}=\alpha_{0}+\alpha_{2} t+\vartheta F D I_{t-1}+\sum_{i=1}^{p} \beta_{i} \Delta F D I_{t-i}+\varepsilon_{t}$

Where Equation 3.3 had no intercept and no trend. Equation 3.4 had an intercept but no trend, lastly, equation 3.5 had both intercept and trend. $\vartheta$ represents the coefficient of lagged dependent variable. $F D I_{t-1}$ and $\mathrm{p}$ lags of $\triangle F D I_{t-i}$ with coefficients $\beta_{\mathrm{i}}$ added to account for serial correlation in the residuals. $\alpha_{0}$ represents the intercept (in Equation 3.4). $\alpha_{2} \mathrm{t}$ represents linear time trend (in Equation 3.5). Similarly, the study did the same for the rest of the variables (external balance, net exports, real interest rate, exchange rate, inflation, GDP growth and volatility of oil prices).

The null hypothesis of a series based on the above equations was tested against the alternative hypothesis. The hypotheses are as follows:

$H_{0}: \vartheta=0$ which implies the series has a unit root (has a unit root).

And

$H_{1}: \vartheta<0$ which implies the series is stationary (has no unit root).

Each ADF equation could then be estimated using OLS and its t-statistic given by;

$A D F_{t}=t_{\delta=1}=\frac{\hat{\vartheta}}{S E(\hat{\vartheta})}$

$S E(\vartheta)$ represents the standard error for $(\vartheta)$ and denotes estimate. The null hypothesis of unit root was accepted if the t-statistics is greater than the critical values.

Philip-Perron (PP) Test

The test was carried out under the' null hypothesis that $\rho=0$, the PP Zt and Z $\pi$ statistics had the same asymptotic' distributions as the' ADF t-statistic and normalized bias statistics. One advantage of the PP tests over the ADF tests is that the PP tests are robust to general forms of heteroskedasticity in the error term $\varepsilon_{t}$. Another advantage is that the user does not have to specify a lag length for the test regression.

Testing for Cointegration

Cointegration analysis was conducted to establish whether there was a correlation between the selected time series variables in the long run. Syczewska (2011) stated that cointegration analysis is used to test stationarity in linear relationships between non-stationary variables in a time series through use of the vector autoregressive model. Adopting a VAR framework, the study assumed a vector $\beta$ t defined by $m$ endogenous variables since the variables in consideration mutually impact one another. With $\beta \mathrm{t}$ as a general unrestricted VAR (p) model for m-dimensional 
vector $\beta \mathrm{t}$ with $\mathrm{z}$ lags, the equation could then be represented as shown in equation 3.6a:

$\beta_{t}=\varphi_{1} \beta_{t-1}+\varphi_{2} \beta_{t-2}+\cdots+\varphi_{z} \beta_{t-z}+\varepsilon_{t}$

Where,

1. $\beta_{t}$ is $\mathrm{m} \times 1$ vector of $\mathrm{I}(1)$ variables

2. $\varphi_{j}$ is $\mathrm{m} \times \mathrm{m}$ matrix of coefficient for $\mathrm{j}=1,2,3, \cdots, \mathrm{z}$ which represent the coefficients for estimated

3. $\varepsilon_{t}$ is $\mathrm{m} \times 1$ vector of error terms which form an independently and identically distributed (i.i.d) $\mathrm{m}$ dimensional vector with zero mean and variance matrix $\sum \varepsilon, \mathrm{N}(0, \sigma)$ i.e. white noise error terms

Equation 3.6a could then be converted into its Vector Error Correction Model (VECM) form as provided in equation 3.6b:

$\Delta \beta_{\mathrm{t}}=\Gamma_{1} \Delta \beta_{\mathrm{t}-1}+\cdots+\Gamma_{\mathrm{z}-1} \Delta \mathrm{y}_{\mathrm{t}-\mathrm{z}+1}+\Pi \beta_{\mathrm{t}-\mathrm{z}}+\varepsilon_{\mathrm{t}}$

$$
\mathrm{t}=1, \cdots, T
$$

In Equation 3.6b, $\Pi$ represented the rank of the coefficient matrix which was given by the number of independent cointegrating vectors of $\beta \mathrm{t}$. The rank of $\Pi$ could be in one of three forms. A null matrix exists where $\Pi=0$ and this shows there was no cointegration and suggested that the model was a first difference VAR. A full rank exists where $\Pi=\mathrm{m}$ suggesting all variables in the model are stationary and there is no cointegration. In the third form, $\Pi$ is found to be of rank $r$ whereby $r$ is greater than zero but less than $\mathrm{k}$.

Through use of the Johansen procedure for maximum likelihood testing, $\Pi$ can be presented as a product of two matrices $\left(\pi=\lambda \delta^{\prime}\right)$, such that $\lambda$ is defined as two matrices i.e. one being a matrix of $\mathrm{k} \times \mathrm{r}$ and another being a matrix of speed of adjustment of parameters. $\delta$ is a matrix of $\mathrm{r}$ multiplied by $\mathrm{k}$ which is one of cointegrating parameters. Moving on to substitute the modification of $\pi=\lambda \delta^{\prime}$ in the Equation 3.6b yields Equation 3.6c:

$\Delta \beta_{t}=\lambda e c m_{t-z}+\Gamma_{1} \Delta \beta_{t-1}+\cdots+\Gamma_{p-1} \Delta \beta_{t-z+1}+\varepsilon_{t}$

Where, ecm $m_{t-z}=\delta^{\prime} \beta_{t-z}$ is defined as the linear amalgamation presenting the $\mathrm{r}$ cointegrating relationship amid $\beta \mathrm{t}$ variables vector matrix ( $\mathrm{r} \times 1$ ). Equation 3.6c is referred to as Vector Error Correction Model (VECM). This model could be estimated through the maximum likelihood estimation which called for Johansen approach. The Johansen tests are undergirded by two test statistics which are the trace statistic and the maximum eigenvalue statistic. These two tests were deployed for establishing the number of cointegrating vectors within the model.

GARCH Model

Volatility of the price of oil was modelled using the generalized autoregressive conditional heteroscedasticity $(\mathrm{GARCH})$ model. This was informed by the fact that the price of oil is mostly characterized by that is clustering, that is periods in which it is exhibits shocks for an extended time period, followed by a period of comparative tranquility and hence the GARCH model would best capture such volatility clustering and other exogenous economic events that capture such effects on the inflow of FDI.

In particular, the study applied GARCH $(1,1)$; implying that it has one lag variance and one lag residual error to be included in the model. The model is therefore presented in Equation 3.7:

$\sigma_{t}^{2}=\alpha_{0}+\alpha_{1} e_{t-1}^{2}+\beta_{1} \sigma_{t-1}^{2}$

Where $\sigma_{t}^{2}$ represents the conditional variance of the residuals drawn from the preceding mean equation at time t; $\alpha_{0}$ represents the unconditional variance otherwise known as the constant; $e_{t-1}^{2}$, also known as the ARCH term, gives the previous period's squared as obtained from the mean 'equation; $\sigma_{t-1}^{2}$ represents the GARCH term which in essence gives the previous day's residual variance/volatility.

It is equation 3.7 which was estimated in assessing the impact of oil price volatility on FDI inflow in Kenya. Model estimation in this study commenced with analysis of the residuals of the mean equation, through running an ordinary least squares regression, with the goal being showing the volatility that characterizes the independent as well as dependent variables in the study. Plotting these residuals enabled observation of the volatility that characterized each variable.

Multiple Linear Regression Model Equations

The multiple linear regression model was used to estimate the equation linking FDI inflows and global oil price, external balance, exchange rate, inflation, real GDP as well as real interest rate as shown below:

$F D I=\beta_{0}+\beta_{1} G P+\beta_{2} E B+\beta_{3} E R+\beta_{4} I N+\beta_{5} R G+\beta_{6} R I+\varepsilon$

Where:

FDI-FDI Inflows into Kenya

GP-global Price of Oil (USD per Barrel)

EB - External Balance (USD)

ER - Exchange Rate (USD to Kes)

IN - Inflation (Average annual \%)

RG - Real GDP Growth (Annual \%)

RI - Real Interest Rate (Annual \%)

$\beta_{0}$ - Constant term of the model

$\varepsilon$ - Random error term 
The model fitness will be checked using both coefficient of determination $r^{2}$ ( $r$-squared), as well as checking the p-value of the F-statistic. As such, a p-value less than 0.05 implies the model is good.

Additionally, diagnostic tests for the regression model comprised serial correlation, whether the residuals of the model were serially correlated. Tests for heteroskedasticity were also conducted using Breusch-Pagan/CookWeisberg' tests in order to establish whether there was constant variance in the residuals of the model.

\subsection{Results and interpretation}

The first objective of the study sought to model volatility using GARCH model. To start with, time series properties of unit root, cointegration analysis, as well as lag order selection analysis were carried out.

\subsection{Unit Root Tests}

The unit root test analysis established that annual inflation rate, real GDP growth and real interest rate met the conditions of stationary at $5 \%$ level of significance; implying that the two variables were integrated of order zero, $\mathrm{I}(0)$. The global oil price external balance and exchange rate had p- values above 0.05 , which implied that the selected macroeconomic variables were not stationary at $5 \%$ level. The variables were therefore differenced once and were found to be integrated of order one I(1).

\subsection{Cointegration Analysis}

Cointegration analysis was carried out using Johansen methodology which makes use of maximum likelihood (ML) estimator in order to establish a long-term relationship between price of oil and FDI in Kenya and the findings of these tests were summarized in Table 1.

Table 1: Cointegration results

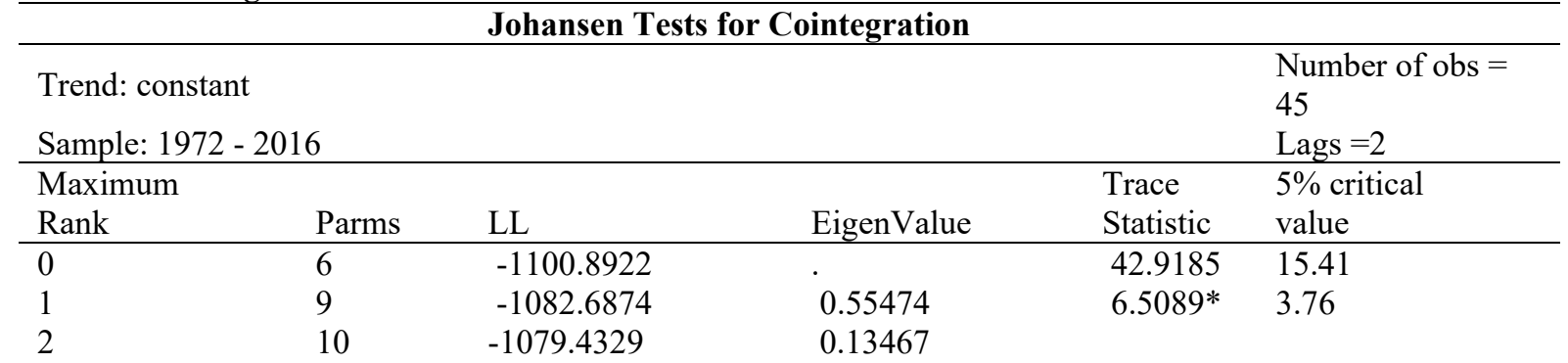

Table 1 gives the results of an analysis of the long-term relationship between the price of oil in the global market and FDI inflows in Kenya.

From the results summarized in Table 1, it is seen that at rank $r=1$, the trace statistic was 1.149 which was far less than the critical value of 3.76. This was a confirmation of the cointegration relationship between the two variables. This implied that there was existence of long-term equilibrium relationship between the price of oil and FDI in the Kenya.

With the confirmation of cointegration relationship, the next step was to establish the Vector Error Correction Model (VECM). This was carried out so as to capture short term dynamics of the price of oil and FDI. The result is summarized in Table 2:

Table 2: Vector Error Correction Model

\begin{tabular}{|c|c|c|c|c|c|c|}
\hline \multirow{2}{*}{ D FDI Inflow Mln } & \multirow[t]{2}{*}{ Coef. } & \multirow[t]{2}{*}{ Std. Err. } & \multirow[t]{2}{*}{$\mathbf{z}$} & \multicolumn{2}{|l|}{$\mathbf{P}>\mathbf{Z}$} & \multirow[b]{3}{*}{-.39684} \\
\hline & & & & & & \\
\hline $\begin{array}{l}\text { L1. } \\
\text { FDI Inflow Mln }\end{array}$ & -.8044153 & .2079483 & -3.870 & 0.000 & -1.2119 & \\
\hline $\begin{array}{l}\text { LD. } \\
\text { Oil Price per barrel }\end{array}$ & .4023991 & .23115 & -1.74 & 0.082 & -.05064 & .855444 \\
\hline $\begin{array}{l}\text { LD. } \\
\text { D Oil Price per barrel }\end{array}$ & -0.468 & 4.204 & -0.110 & 0.911 & -8.708 & 7.773 \\
\hline L1. & 0.029 & 0.013 & 2.170 & 0.030 & 0.003 & 0.054 \\
\hline
\end{tabular}

Table 2 illustrates the VECM results which shows the differenced price of oil yielded a statistically significant coefficient for the first lag

\subsection{Post Estimation Diagnostic Tests}

This section discusses some of the post-estimation diagnostic tests which were conducted in order to establish acceptability of the fitted model.

3.3.1 Serial Correlation Tests

Table 3 provides the summary of the results of the serial correlation test which were conducted in order to establish 
whether the residuals of the model or serially correlated or not.

Table 3: Serial correlation tests

\begin{tabular}{llcc}
\hline Lags(p) & Chi2 & df & Prob> chi2 \\
\hline 1 & 2.033 & 1 & 0.350
\end{tabular}

Table 3 leads us to conclude that there exists no serial correlation in the residuals

It can be observed from Table 3 that the p-value was 0.35 , which is way greater than 0.05 . This led to the acceptance of the null hypothesis that there was no serial correlation in the residuals of the model.

\subsubsection{Heteroskedasticity tests}

Heteroskedasticity tests were conducted Breusch-Pagan tests, in order to establish whether the researchers of the model had constant variance. These findings were summarized in Table 4:

Table 4: Heteroskedasticity tests

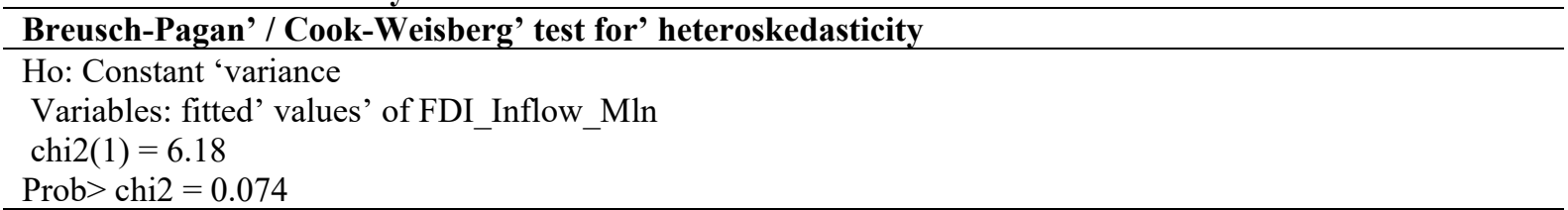

\section{Table 4 shows constant variance or homoscedasticity.}

The results in Table 5 show that the $p$-value for the chi-square statistics, $p=.074$ which was way above 0.05 level of significance therefore leading to acceptance of the null hypothesis that assumed constant variance or homoscedasticity.

\subsection{The trend of global oil price volatility between 1970 and 2016}

The first objective was to analyse the trend of global oil price volatility between the years 1970 and 2016. Firstly, the data for the global oil price was captured in Figure 1:

Figure 1: The trend of oil price volatility between 1970 and 2016

120.0

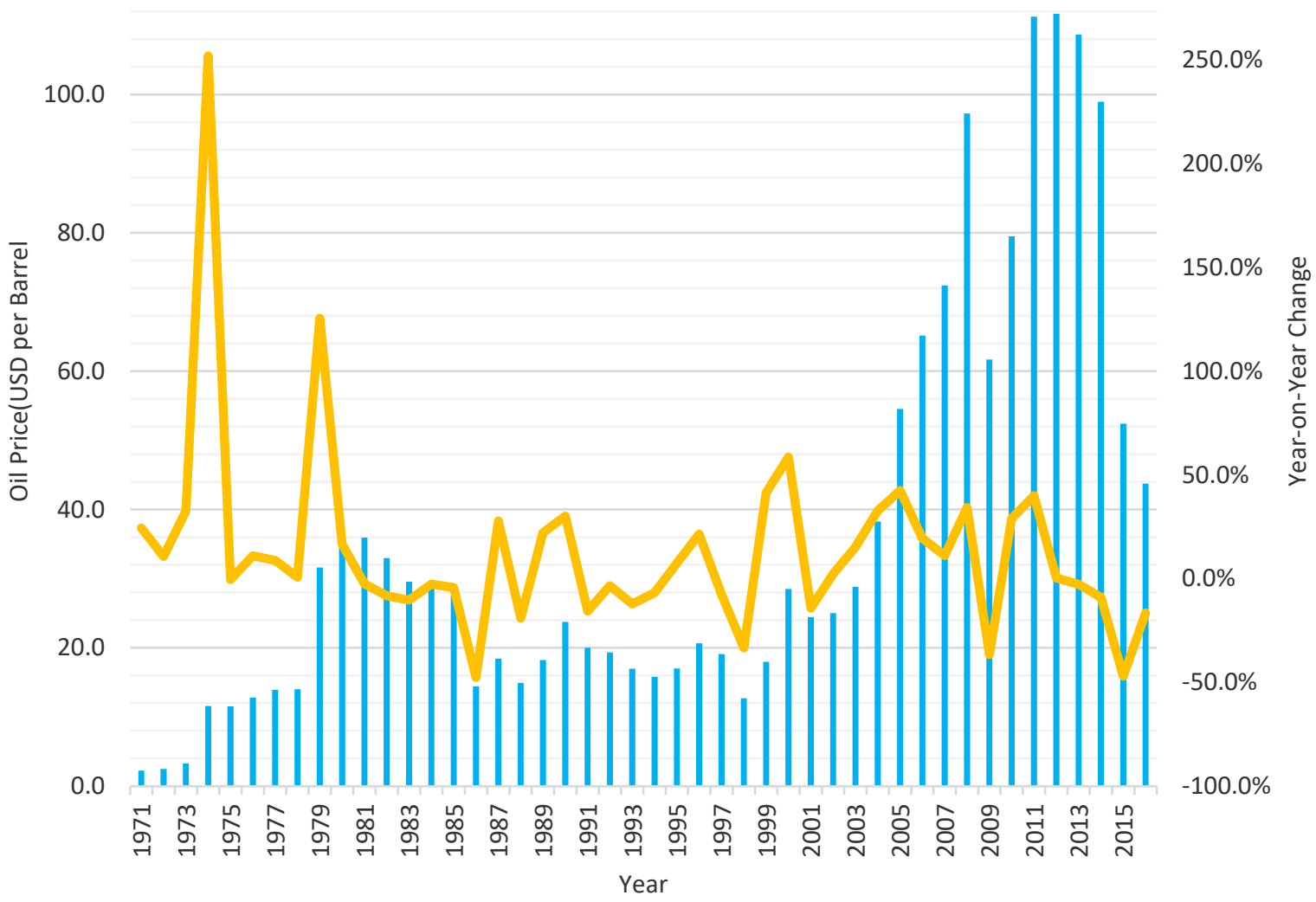

Figure 1 shows the trend in year-on-year change in the price of oil

Figure 1 shows that the price of oil rose between the years 1970 and 1980. A similar trend was observed between 
the years 1998 all the way up to 2012. The volatility of the global price of oil also fell between the years 1990 and 2000 and also immediately after the year 2012 up to 2016. Statistical analysis was done on the data in order to determine global oil price volatility using autoregressive conditional heteroskedasticity ARCH $(1,1)$ model. The findings were summarized in Table 6:

Table 5: ARCH results for global oil price volatility between 1970 and 2016

\begin{tabular}{|c|c|c|c|c|c|c|}
\hline Global Price of Oil (USD per Barrel) & Coef. & $\begin{array}{l}\text { Std. } \\
\text { Err. }\end{array}$ & $\mathbf{z}$ & $\mathbf{P}>\mathbf{Z}$ & {$[95 \%$ Conf. } & Interval] \\
\hline \multicolumn{7}{|l|}{ Global Price of Oil (USD per Barrel) } \\
\hline _cons & 19.810 & 0.931 & 21.26 & 0 & 17.98365 & 21.636 \\
\hline \multicolumn{7}{|l|}{$\mathrm{ARCH}$} \\
\hline \multicolumn{7}{|l|}{$\operatorname{arch}$} \\
\hline L1. & 1.032 & 0.467 & 2.21 & 0.027 & 0.115617 & 1.9484 \\
\hline cons & 15.789 & 9.410 & 1.68 & 0.093 & -2.65399 & 34.233 \\
\hline
\end{tabular}

Table 5 shows a statistically significant relationship between the price of oil and its first lag

From Table 6, the regression coefficient for the first lag had a p-value of 0.027 , which was less than 0.05 . This showed that there was a statistically significant relationship between the price of oil and its first lag.

\subsection{Garch Model}

The Garch $(1,1)$ model was used in order to estimate the volatility of the oil price and the results were summarized in Table 27.

Table 6: GARCH model results

\begin{tabular}{|c|c|c|c|c|c|c|}
\hline Global price of oil per barrel & Coef. & Std. Err. & $\mathbf{z}$ & $\mathbf{P}>\mathbf{Z}$ & $\begin{array}{l}{[95 \%} \\
\text { Conf. }\end{array}$ & Interval] \\
\hline \multicolumn{7}{|l|}{ Global price of oil per barrel } \\
\hline cons & 19.78891 & 1.046405 & 18.91 & 0 & 17.73799 & 21.83982 \\
\hline \multicolumn{7}{|l|}{$\mathrm{ARCH}$} \\
\hline \multicolumn{7}{|l|}{$\operatorname{arch}$} \\
\hline L1. & 1.022634 & 0.494996 & 2.07 & 0.039 & 0.05246 & 1.992808 \\
\hline \multicolumn{7}{|l|}{ garch } \\
\hline L1. & 0.011041 & 0.340061 & 0.03 & 0.974 & -0.65547 & 0.677549 \\
\hline cons & 15.36163 & 14.48663 & 1.06 & 0.289 & -13.0316 & 43.7549 \\
\hline
\end{tabular}

Table 6 shows the first lag values of the GARCH model were not significant predictors of the volatility of the price of oil.

The results in Table 6 show that lag 1 coefficient, $\mathrm{L} 1=0.01104, \mathrm{z}(46)=.03, \mathrm{p}>.05$, implying the first lag values of the GARCH model were not significant predictors of volatility of the price of oil.

3.6 Establishing the effect of global oil price volatility on FDI inflows in Kenya The second objective of this study was to establish the effect of global oil price volatility on FDI inflows in Kenya. This was analyzed using multiple linear regression model. The results of the model summary are shown as follows: 
Table 7: Model summary and analysis of variance

\begin{tabular}{ccccccc}
\hline Source & SS & df & MS & Number of obs & $=$ & 47 \\
\hline \multirow{2}{*}{ Model } & $2.30 \mathrm{E}+18$ & 6 & $3.8406 \mathrm{e}$ & Prob $>\mathrm{F}$ & $=$ & 0.000 \\
\multirow{2}{*}{ Residual } & $1.13 \mathrm{E}+18$ & 40 & $2.8314 \mathrm{e}$ & R-squared & $=$ & 0.6705 \\
& & & & Adj R-squared & $=$ & 0.621 \\
& & & & & & \\
Total & $3.44 \mathrm{E}+18$ & 46 & $7.4716 \mathrm{e}$ & Root MSE & $=$ & $1.70 \mathrm{E}+08$
\end{tabular}

Table 7 shows the selected macroeconomic variables explain a significant proportion of variance in FDI inflows.

The results and Table 7 indicate that the selected macroeconomic variables explained a significant proportion of variance in FDI inflows, $\mathrm{R} 2=.6706, \mathrm{~F}(6,40)=13.56, \mathrm{p}<.05$. This implies that the model was fit therefore to explain the relationship between the selected macroeconomic variables. Furthermore, the results of the regression analyses were summarized in Table 10:

Table 8: Multiple linear regression model

\begin{tabular}{lcccccc}
\hline FDI Inflows into Kenya & Coef. & Std. Err. & $\mathbf{t}$ & P>t & $\begin{array}{c}\text { [95\% } \\
\text { Conf. }\end{array}$ & Interval] \\
\hline $\begin{array}{l}\text { Global Price of Oil (USD per } \\
\text { Barrel) }\end{array}$ & -7969894 & 1808790 & -4.41 & 0.000 & -11600000 & -4314194 \\
External Balance (USD) & -0.158033 & 0.025 & -6.33 & 0.000 & -0.208472 & -0.108 \\
Exchange Rate (USD to Kes) & 983309.1 & 1313710 & 0.750 & 0.459 & -1671798 & 3638416 \\
Inflation (Average annual \%) & 2514802 & 3545489 & 0.710 & 0.482 & -4650898 & 9680502 \\
Real GDP Growth (Annual \%) & 1954893 & 6539972 & 0.300 & 0.767 & -11300000 & 15200000 \\
Real Interest Rate (Annual \%) & -6396840 & 4236774 & -1.51 & 0.139 & -15000000 & 2166001 \\
cons & 107000000 & 82200000 & 1.300 & 0.201 & -59200000 & 273000000 \\
\hline
\end{tabular}

Table 8 shows the summary regression model of the effect of global oil price volatility on FDI inflows in Kenya

The findings in Table 8 indicate that exchange' rate, inflation and real GDP had positive coefficients. However, their respective $\mathrm{p}$-values more than 0.05 . This 'led to the conclusion that these coefficients were statistically insignificant.

Three variables (global oil volatility, external balance and real interest rate) had negative coefficients. The coefficients of global oil volatility and external balance were statistically significant, whereas that of the real interest rate was statistically insignificant. This finding is in agreement with that of Yazdanian (2014) who found that the price of oil had a negative influence 'on FDI. Similarly, Ashja and Ostadi (2014) found that external balance had a negative influence on FDI.

On the basis of the empirical findings, the present study summarizes the relationship between the selected macroeconomic variables using the following multiple linear regression model:

FDI = -7969894 Global Price of Oil (USD per Barrel) - 0.158033External Balance (USD) + 983309.1 Exchange Rate (USD to Kes) + 2514802 Inflation (Average annual \%) + 1954893 Real GDP Growth (Annual \%) - 6396840 Real Interest Rate (Annual \%)

The model can therefore provide a good basis of establishing how foreign direct investment inflows in Kenya can be influenced by not only the shocks resulting from there all prices at global level but also various selected macroeconomic variables.

\subsection{Conclusion and recommendations}

This section briefly outlines conclusions recommendations and policy implications. 


\subsection{Conclusion}

The study therefore makes the following conclusions:

1. There was a rise in the volatility depicted by the global price of oil between 1973 and 2016 compared to the period between 1950 and 1972.

2. Volatility of oil prices has a significant negative effect on FDI inflows into Kenya.

\subsection{Recommendation}

Additional studies can be conducted using different methodological approach. As such, panel data analysis can be used in analyzing oil price volatility and its influence on FDI inflows in different context.

\subsection{Policy implications}

The following policy implications are spelt out:

1. In light of how FDI is influenced by Global oil price volatility, the policy implementation should be directed in such a way as to realize sustainable inflow of FDI in the event of shocks in the Global oil price. This will be critical bearing in mind that Kenya is prospecting to join the League of oil exporting countries in the near future following discovery of oil in Lake Turkana.

2. In line with the first recommendation, it is imperative that a necessary regulatory framework designed to govern Kenya's proceed from oil be strengthened. As such, The Draft Sovereign Wealth Fund Bill of 2019 which provides for establishment of a Stabilization Fund into which at least 15.0 per cent of oil revenues will be channeled becomes an important step forward.

\subsection{Possible further research direction}

The present study's focus was on Kenya, however considering that other East African countries such as Uganda have plans to export crude oil, a broad based research, with replication of similar macroeconomic variables mapping all East African community countries would provide critical insights pertaining to the trend of oil price volatility, and possibly shed light of how FDI inflows in the region would be impacted on by global oil price volatility.

\section{References}

Abdulkarim, F. M., Akinlaso, M. I., Hamid, B. A., \& Ali, H. S. (2020). The nexus between oil price and Islamic stock markets in Africa: A wavelet and Multivariate-GARCH approach. Borsa Istanbul Review, 20(2), 108120.

Adejumobi, A. R., \& Julius, O. O. (2017). Oil Price Shocks and Foreign Direct Investment (FDI): Implications for Economic Growth in Nigeria (1980-2014). Journal of Economics and Sustainable Development, 8(4).

Ahmed, S. M. (2016). The Impact of Oil Prices on the Economic Growth and Development in MENA Countries. Middle East Economic Association.

Alao, R. O., \& Payaslioglu, C. (2021). Oil price uncertainty and industrial production in oil-exporting countries. Resources Policy, 70, 101957.

Amin, S. B., Marsiliani, L., \& Renström, T. I. (2015). Macroeconomic Impacts of Oil Price Shocks on the Bangladesh Economy. Indian Statistical Institute, Delhi Centre.

Ashja, S. \& Ostadi, H. (2014). The relationship between external debt and foreign direct investments in D8 member countries (1995-2011), Walla Journal, 30 (S3): 18-22.

Basemera, S., \& Mutenyo, J. (2012). Foreign Direct Investment Inflows to East Africa: Do Institutions Matter? Journal of Business Management and Applied Economics.

Beghum. N., Sannassee. R., Seetanah. B., \& Lamport, M. (2011). On the Determinants of Foreign Capital Flows: Evidence from an African economy. University of Mauritius.

Blinder, A., \& Rudd, J. (2008). The Supply Shock Explanation of the Great Stagflation Revisited. Princeton University.

Boughton, J. M. (2002). Origins of the Fleming-Mundell Model (IMF Working Paper). International Monetary Fund.

Chatziantoniou, I., Filippidis, M., Filis, G., \& Gabauer, D. (2021). A closer look into the global determinants of oil price volatility. Energy Economics, 95, 105092.

Chege, I. (2015). Impact of Foreign Direct Investments on Economic Growth in Kenya (1984-2013). International Journal of Economics, Commerce and Management, 3(11). Retrieved August 29, 2017.

Elheddad, M., Thapa-Parajuli, R., \& Alharthi, M. (2020). Foreign Direct Investment (FDI) and Natural Resources: Blessing or Curse? Empirical Evidence from the Gulf Cooperation Council (GCC). Journal of Reviews on Global Economics, 9, 232-241.

Fazira, D. R., \& Cahyadin, M. (2018). The Impact of Interest Rate, Corruption Perception Index, and Economic Growth on Foreign Direct Investment in ASEAN-6. Jurnal Keuangan dan Perbankan, 22(4). 
Feiguine, G., \& Solovjova, J. (2014). Significance of Foreign Direct Investment for the Development of Russian ICT sector. University of Wuppertal.

Fleming, M. (1962). Domestic financial policies under fixed and under floating exchange rates. International Monetary Fund Staff Papers, 9 (3)

Francis, N., \& Restrepo-Angel, S. (2018). Sectoral and aggregate response to oil price shocks in the Colombian economy: SVAR and Local Projections approach. Borradores de Economía; No. 1055.

Gachara, P. M. (2015). Transmission Channels of Crude Oil Price Shocks on Kenya's Economy. Nairobi: Kenyatta University.

Gandorfer, M., Porsch, A., \& Bitsch, V. (2017). Producer price volatility in the German fruit and vegetable industry. European Journal of Horticultural Science, 82(3), 149-154.

Habimana, S. (2018). Analysis of the Determinants of Foreign Direct Investment in Rwanda (Period of 19702010): Econometric Approach. Organization, 6(3).

Hachula, M., \& Rieth, M. (2020). Estimating the Impact of Financial Investments on Agricultural Futures Prices using Changes in Volatility. American Journal of Agricultural Economics, 102(3), 759-785.

Haider, M., Gul, S., Afridi, S. A., \& Batool, S. (2017). Factors Affecting Foreign Direct Investment in Pakistan. NUML International Journal of Business \& Management, 12(2), 136-149.

Harris, L. (2009). Capital flows and policy in emerging-market economies. Reserve Bank of South Africa.

Hayee, S. A., Jameel, K., Hussain, S., \& Ul Hasan, S. (2016). Empirical Analysis of Macroeconomic Determinants on Foreign Direct Investment Inflows in Pakistan (11th ed., Vol. 6). Developing Country Studies.

Hou, Z., Keane, J., Kennan, J., \& Willem te Velde, D. (2015). The oil price shock of 2014: Drivers, impacts and policy implications (Working Paper 415). Overseas Development Institute.

International Monetary Fund. (2017). Sub-Saharan Africa: Restarting the Growth Engine. Washington, DC: International Monetary Fund.

Johansen, S., \& Juselius, K. (1990). Maximum Likelihood Estimation \& Inference on Cointegration (2nd ed., Vol. 52). Oxford Bulletin of Economics \& Statistics.

Johnson, S. R., Zuber, R. A., \& Gandar, J. M. (2006). A Re-Examination of the Mundell-Fleming Flexible Exchange-Rate Model. Journal of Economics \& Finance Education.

Jugurnath, B., Chuckun, N., and Fauzel, S. (2016). Foreign Direct Investment \& Economic Growth in Sub-Saharan Africa: An Empirical Study. Scientific Research Publishing.

Kenya National Bureau of Statistics. (2017). Economic Survey. Nairobi: Kenya National Bureau of Statistics.

Kiiru, J. O. (2014). Exploring Determinants and Effects of Foreign Direct Investment: The Case of Sub-Saharan Africa. University of Massachusetts Boston.

Klein, T., \& Walther, T. (2016). Oil price volatility forecast with mixture memory GARCH. Energy Economics, $58,46-58$.

Lindström, V., \& Sten, E. (2018). The relationship between foreign direct investments and exchange rates-A quantitative analysis of how the exchange rate is affecting the FDI inflows in South Korea and China.

Lv, K., Cheng, Y., \& Wang, Y. (2020). Does regional innovation system efficiency facilitate energy-related carbon dioxide intensity reduction in China?. Environment, Development and Sustainability, 1-25.

Lyu, Y., Tuo, S., Wei, Y., \& Yang, M. (2021). Time-varying effects of global economic policy uncertainty shocks on crude oil price volatility: New evidence. Resources Policy, 70, 101943.

Makau, A. (2017). Multivariate Regression Analysis of Oil Price Volatility on GDP Growth in Kenya (1st ed., Vol. 6). American Journal of Theoretical and Applied Statistics.

Mijiyawa, A. G. (2012). What Drives Foreign Direct Investments in Africa? An Empirical Investigation with Panel Data. Accra: African Center for Economic Transformation.

Mundell, R. (1963). Capital mobility and stabilization under fixed and flexible exchange rates. Canadian Journal of Economics and Political Science, 29.

Njoroge, S. M. (2016). Determinants of Foreign Direct Investment Growth in Kenya. Nairobi: Jomo Kenyatta University of Agriculture \& Technology.

Otieno, G., \& Njuguna, A. (2016). The Influence of Macro-Economic Factors on Foreign Direct Investment Flows in Kenya for the Period of 2002-2013 (8th ed., Vol. 6). Developing Country Studies.

Sanchez, M. V. (2011). Welfare Effects of Rising Oil Prices in Oil-Importing Developing Countries. Institute of Developing Economies.

Sikdar, S. (2008). Capital Inflow into Developing Economies: A Macroeconomic Study (Discussion Paper No. 725). Institute of Social and Economic Research Osaka University.

Sohail, S., \& Mirza, S. S. (2020). Impact of Foreign Direct Investment on Economic Growth of Pakistan. Asian Journal of Economics, Finance and Management, 1-13.

Syczewska, E. M. (2011). Cointegration since Granger: Evolution and Development (Vol. 12). Quantitative Methods in Economics.

Talwar, S., \& Srivastava, S. (2018). Integration of GDP and FDI in Economies at Different Stages of Growth. 
Theoretical Economics Letters, 8(11), 2199.

Toews, G., \& Vézina, P. (2016). Resource Discoveries and FDI Bonanzas. University of Oxford.

Troiano, L., \& Villa, E. M. (2020). A measure of market volatility based on F-transform. Fuzzy Sets and Systems, 395, 199-216.

Tumusiime-Mutebile, E. (2015, February 25). The impact of oil price volatility and its implications for the economy and for macroeconomic stability. Retrieved August 29, 2017, from http://www.bis.org/review/r150304j.htm

United Nations Conference on Trade \& Development (2012). An Investment Guide to Kenya: Opportunities \& Conditions. United Nations.

Wagner, D. (2016, May). Low Oil Price and Its Impact on FDI in MENA. Huffington Post.

Weeks, J. (2008). A Note on Mundell-Fleming and Developing Countries (Department of Economics Working Papers). University of London.

Welfens, P. J. (2011). Innovations in Macroeconomics (3rd ed.). Springer.

Wynne, M. (2007). How have small open economies responded to the challenge of globalization? Federal Reserve Bank of Dallas, Research Department, Bank of Iceland conference on "The Challenges of Globalization for Small Open Economies with Independent Currencies".

Yazdanian, N. (2014). Investigation of the Determinants of Foreign Direct Investment in Oil-Producing Countries. International Journal of Economy, Management and Social Sciences, 3(12), 65-70. 